\title{
INTERFERENCE OF SOIL COMPACTION ON DICLOSULAM RESIDUAL
}

\section{INTERFERÊNCIA DA COMPACTAÇÃO DO SOLO NO RESIDUAL DO DICLOSULAM}

Amanda dos Santos Souza ${ }^{\mathrm{a}}$, Jéssica Ferreira Lourenço Leal ${ }^{\mathrm{a}}$, Ana Claudia Langaro ${ }^{\mathrm{a} *}$, Felipe Cipriano da Silva ${ }^{\mathrm{a}}$, Camila da Costa Barros de Souza ${ }^{\mathrm{b}}$, Marcos Gervasio Pereira $^{\mathrm{b}}$, Camila Ferreira de Pinho ${ }^{\mathrm{a}}$

${ }^{a}$ Departamento de Fitotecnia, Universidade Federal Rural do Rio de Janeiro, Rio de Janeiro, Brasil. ${ }^{\text {b }}$ Departamento de Solos, Universidade Federal Rural do Rio de Janeiro, Rio de Janeiro, Brasil.

*Autor correspondente: langaro.ac@gmail.com.

\section{INFORMAÇÕES DO ARTIGO}

\section{Histórico do artigo:}

Recebido: 28 Agosto 2019.

Aceito: 02 Abril 2020.

Publicado: 13 Abril 2020.

\section{Keywords/Palavras-chave:}

Carryover/Carryover.

Cucumis sativus/Cucumis sativus.

Glycine max/ Glycine max.

Selectivity/ Seletividade.

Soil density/ Densidade do solo.

Zea mays/Zea mays.

\section{Financiamento:}

Fundação Carlos Chagas Filho de Amparo à Pesquisa do Estado do Rio de Janeiro (FAPERJ) and the Coordenação de Aperfeiçoamento de Pessoal de Nível Superior (CAPES).

Direito Autoral: Este é um artigo de acesso aberto distribuído sob os termos da Licença Creative Commons, que permite uso, distribuição e reprodução irrestritos em qualquer meio, desde que o autor e a fonte originais sejam creditados.

\section{Citação deste artigo:}

SOUZA, A. S.; LEAL, J. F. L.; LANGARO, A. C.; SILVA, F. C.; SOUZA, C. C. B.; PEREIRA, M. G.; PINHO, C. F. Interference of soil compaction on diclosulam residual. Revista Brasileira de Herbicidas, v. 18, n. 4. 2019.

\begin{abstract}
The residual herbicides in the soil can be influenced by several factors, including soil compaction. The objective of this study was to evaluate the influence of soil compaction on selectivity of diclosulam to soybean, as well as the carryover effect on the corn in succession. The experiment was carried out in clay and sandy soil. The experimental design was in a randomized block with four replicates. The treatments were arranged in a $3 \times 3$ factorial scheme, where A factor was level of compaction ( 0 - no compaction, 10 and $20 \%$ ) and the B factor doses of diclosulam $\left(0,25.2\right.$ and $\left.50.4 \mathrm{~g}_{\text {ai }} \mathrm{ha}^{-1}\right)$ applied in pre-emergence of soybean. After soybean harvested, the columns were opened and corn and cucumber were seeding. The analyzes carried out on soybean were chlorophyll $a$ fluorescence, shoot dry matter (SDM) and NPK content at 90 days after germination (DAG). For corn: chlorophyll $a$ fluorescence transient was performed at 15, 30 and 45 DAG. For corn and cucumber: plant height, root length, SDM and root dry mass at 45 DAG. The herbicide residue quantification was performed by LC-MS/MS at 94 days after application. Data were submitted to ANOVA $(\mathrm{p} \leq 0.05)$ and the means were compared by Tukey at $5 \%$. Soybeans plants in both soils showed no difference in growth parameters and NPK content but photosynthesis parameters was impaired. There was no corn crop carryover regardless of soil compaction. There was a reduction of cucumber plants being aggravated in soils with compaction. No diclosulam residue was detected in solutions evaluated by LC-MS/MS.
\end{abstract}

\section{RESUMO}

O residual do herbicida no solo pode ser influenciado por diversos fatores incluindo a compactação do solo. O objetivo foi avaliar a influência dos níveis de compactação do solo na seletividade do herbicida diclosulam para a soja e efeito carryover no milho semeado em sucessão. O delineamento foi em blocos casualizados com 4 repetições. Os tratamentos em esquema fatorial $3 \times 3$, o fator $\mathrm{A}$ compactação $(0,10$ e $20 \%)$ e o fator B as doses do herbicida diclosulam $(0 ; 25.2$ e 50.4 g i.a. ha ${ }^{-1}$ ) aplicado em pré-emergência. Após 90 dias da semeadura da soja, foi realizada coleta das plantas, abertura das colunas e semeados milho e pepino. Foram realizadas na soja as análises: fluorescência da clorofila $a$, massa seca da parte aérea (MSPA) e conteúdo de NPK das folhas aos 90 dias após a germinação (DAG). Para milho: fluorescência da clorofila $a$ aos 15, 30 e 45 DAG. Para milho e pepino: estatura de plantas, comprimento das raízes, MSPA e massa seca da raiz aos 45DAG. A quantificação do resíduo do diclosulam por LC-MS/MS foi realizada aos 94 dias após aplicação do herbicida. Os dados foram submetidos à ANOVA $(p \leq 0,05)$ e comparadas pelo teste de Tukey a $5 \%$. A soja em ambos os solos, não apresentou diferença nos parâmetros de crescimento e conteúdo de NPK, porém houve prejuízo nos parâmetros fotossintéticos. Não houve carryover causado a cultura do milho, independente da compactação do solo. Houve redução das plantas de pepino sendo agravado em solos compactados. Não foi detectado resíduo do diclosulam nos solos avaliados por LC-MS/MS. 
SOUZA, A. S et al.

\section{Introduction}

The intense use of machinery by agricultural practices favor soil compaction and has influence in chemical, physical and biological processes (SORACCO et al., 2015). The compaction depends on the type of soil, the water content and initial compaction environment (SECCO et al., 2009). The main negative effects of soil compaction are restriction on root growth, soil aeration reduction, water percolation (CHEN; WEIL; HILL, 2014) and influence on herbicide dynamics (ZOBIOLE et al., 2007).

The herbicides are among the agricultural inputs most used in agricultural activities, being employed in areas of great extension. However, it is necessary to know about the interaction between the chemical and physical characteristics of the soil and the behavior of these molecules in the environment, since these characteristics besides altering the persistence, can change the effectiveness and selectivity of the herbicide for crops of economic interest (BLANCO, 1979; GAZOLA et al., 2016).

The herbicide permanence in the soil in time that exceeds the crop in which it was applied may result in a negative effect on crops grown in succession, a phenomenon known as carryover (MELO et al., 2016). The carryover potential of a herbicide depends on the characteristics of the molecule, the physical-chemical characteristics of the soil and the environmental conditions, such as soil compaction, which is intensified according to production systems. Soil density may affect herbicide activity by altering the diffusion of its molecules in the soil (FERRI et al., 2000).

Among the main pre-emergent herbicides used in soybean system and with potential to cause carryover in crops in succession, we can mention diclosulam. In previous works, it was observed that the sunflower sown 200 days after the application of the herbicide showed high sensitivity to the herbicide residual in the soil (DAN et al., 2012). This herbicide acts by inhibiting the enzyme acetolactate synthase (ALS) and belongs to the chemical group of sulfonanilides. The diclosulam is indicated for broadleaf control pre-sowing or pre-emergence, presents fairly low partition values $(\mathrm{Kd})$, demonstrating that it has vertical movement potential in the soil. Herbicide leaching is facilitated by water solubility (124 ppm at $\mathrm{pH} 7.0$ and 117 ppm at pH 5.0), acid ionization constant (pKa) of 4.09 and octanol/water partition coefficient (Kow) of 1.42 (SENSEMAN, 2007).

The efficacy of residual herbicides, such as diclosulam, is strongly influenced by soil characteristics. The potential of vertical movement can still be influenced by the degree of soil compaction, since the greater compaction reduces the infiltration and consequently the percolation of the water, which can increase the availability of the herbicides applied to the soil, increasing the absorption and the potential of injury in the crops (ZOBIOLE et al., 2007).

The objective of this study was to evaluate the influence of soil compaction levels on the selectivity of the diclosulam to the soybean crop, as well as the possible carryover effect on the corn sown in the next season.

\section{Material and methods}

Two experiments were carried out in an experimental area, from February to July, 2016. The first and second experiments were carried out in clayey and sandy soil, respectively. For both soils, liming in the proportion of 1.25 $\mathrm{kg} \mathrm{m}^{-2}$ of limestone $80 \%$ PRNT was carried out according to the recommended for soybean cultivation. The physicochemical characteristics are presented in Table 1.

Table 1. Physical-chemical characteristics of soils.

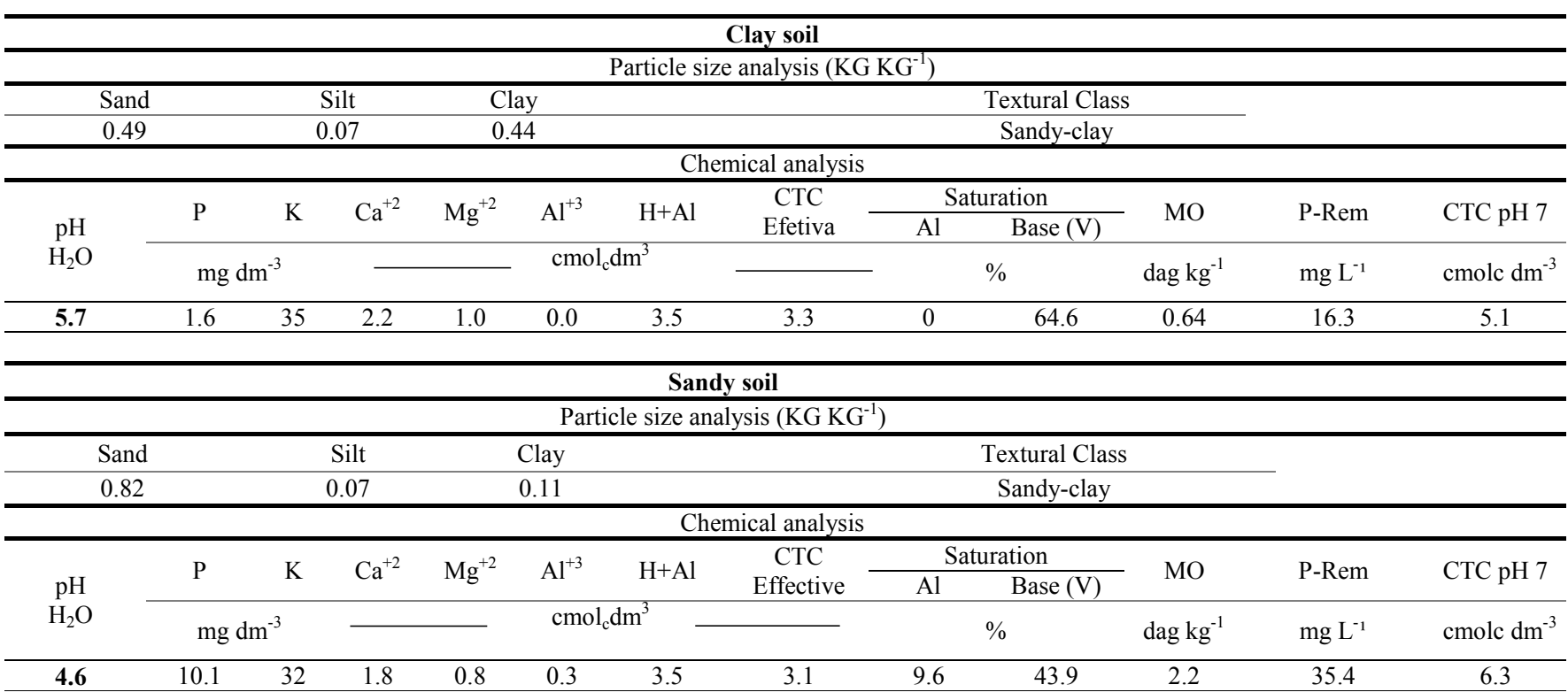

Analysis carried out at the Laboratory of Soil Analysis, Plant Tissue and Fertilizers of the Department of Soils at the University of Viçosa; pH-Potential Hydrogenion; P- Phosphorus; K- Potassium; $\mathrm{Ca}^{+2}$-Calcium; $\mathrm{Mg}^{+2}$-Magnesium; $\mathrm{Al}^{+3}$ - Aluminum; $\mathrm{H}+\mathrm{Al}-\mathrm{Potential}$ Acidity; CTC Effective-Effective Cation Exchange Capacity; CTC-Cation exchange capacity at $\mathrm{pH}$ 7.0; Al- Aluminum saturation index; VSaturation Index by Bases; MO- Organic matter; P-Rem-Remaining Phosphorus. 
SOUZA, A. S et al.

The experimental design was in a randomized block with 4 replicates totaling 36 experimental units in each experiment. The treatments were arranged in a $3 \times 3$ factorial scheme, where factor A was three levels of soil compaction (0 - no compaction, 10 and $20 \%$, respectively corresponding to soil densities of $1.04,1.16$ and $1.28 \mathrm{mg} \mathrm{m}^{-3}$ for clay soil and $1.35,1.48$ and $1.59 \mathrm{mg} \mathrm{m}^{-3}$ for sandy soil) and the factor $\mathrm{B}$ doses of diclosulam (Spider ${ }^{\circledR} 840 \mathrm{WG}, 840 \mathrm{~L}^{-1} \mathrm{~g}$ ai, WG, Dow AgroSciences) 0, 25.2 and $50.4 \mathrm{~g}^{\mathrm{ai} \mathrm{ha}} \mathrm{ha}^{-1}$. The $25 \mathrm{~g}$ ai $\mathrm{ha}^{-1}$ is an intermediate dose, based on the recommended label interval and the $50.4 \mathrm{~g}$ ai ha ${ }^{-1}$ dose to simulate the extreme condition of overlapping spray.

The experimental units were leach columns, made of PVC, $0.6 \mathrm{~m}$ long and $0.2 \mathrm{~m}$ in diameter, filled with sieved soil (clay or sandy soil) and with no history of herbicide applications. In the basal part of the columns were placed screens to retain the soil and to allow the water to drain, since the columns were kept in an upright position in a wooden box with $0.15 \mathrm{~m}$ of gravel (to avoid accumulation of the leaching water inside the column). The box was filled with soil up to the maximum height of the column, to avoid excessive heating of the columns by direct exposure to sunlight. Soil compaction was performed according to the methodology used by Müller, Ceccon e Rosolem (2011), where the soil was compacted with the use of compacting equipment varying the number of blows with the equipment until reaching the desired soil density. The soil inside the columns was compacted with the aid of a $4 \mathrm{~kg}$, in the geometric center of a steel support with a diameter of 0.19 $\mathrm{m}$. For soil compaction, $5 \mathrm{~L}$ of soil were added to the leaching soil columns forming layers inside the columns. The soil layers due to the free fall of the plunger were compacted until reaching height of $0.4 \mathrm{~m}$. According to the blows the density was reached of 1.16 and $1.28 \mathrm{mg} \mathrm{m}^{-3}$ (clay soil at 10 and $20 \%$ ) and 1.48 and $1.59 \mathrm{mg} \mathrm{m}^{-3}$ (Sandy soil at 10 and $20 \%$ ). After compaction, $0.1 \mathrm{~m}$ of soil was added in all columns with their respective soils (clay and sandy) forming a layer without compaction.

The soybean was sown and then the herbicides were applied to the surface of the columns using a $\mathrm{CO}_{2}$ pressurized backpack sprayer with two AXR 110.015 bar and $310 \mathrm{kPa}$ pressure, applying a volume corresponding to $150 \mathrm{~L} \mathrm{ha}^{-1}$. Four seeds of cv. BMX RR Potência were sown at the top of each column and the thinning performed after establishment, maintaining the final population of 2 plants per experimental unit. Before sowing, the inoculation of soybean seeds was carried out, and subsequent management was carried out according to the recommendation for the soybean crop.

At 90 days after sowing, the soybean plants were collected and the columns were opened vertically with the aid of a metal plate, providing two subunits per experimental unit. In the middle of the subunit of each treatment, corn (Zea mays), 2B610PW C3M - CRUISER hybrid and cucumber (Cucumis sativus) were sown in the other half, being this bioindicator of the residue of the herbicide diclosulam. Cucumis sativus is a good bioindicator of the residue of the herbicide in the soil, as observed in a previous experiment, where it was sensitive to the presence of the trifloxysulfuron-sodium and pyrithiobac-sodium herbicides (GUERRA et al., 2011).

The following variables were evaluated: for soybean - chlorophyll $a$ fluorescence transient at 90 days after germination (DAG), plant height, shoot dry matter (SDM) and NPK content of the leaves at 90 days after germination (DAG). For corn - chlorophyll $a$ fluorescence transient at 15, 30 and 45 DAG; plant height, root length, shoot dry mass (SDM) and root dry mass (RDM) at 45 DAG. For the cucumber - plant height, root length (RL), dry shoot mass (SDM) and root dry mass (RDM) at 45 DAG. The diclosulam herbicide residue was extracted by the modified QuEChERS method and quantified by LC-MS/MS at 94 days after application of the herbicide ( 90 days after the germination of the soybean). For this analysis, the soil samples were removed from the leach column, the portion between 10 and $20 \mathrm{~cm}$ from the top of the column (bounded between compacted and non-compacted region), and transferred to a plastic bag, wrapped in a box thermal and frozen. The analyzes were carried out by the Laboratory of Analysis of Pesticide Residues - LARP / UFSM.

Chlorophyll $a$ fluorescence transients were measured in dark-adapted leaves of plants using a Handy-PEA fluorimeter (Plant Efficiency Analyzer, Hansatech Instruments Ltd, UK). Intact young leaves with a fully expanded first leaf still attached to the plant were kept in the dark for at least $20 \mathrm{~min}$ in specially provided clips and measured. The polyphasic fluorescence rise, OJIP, was induced by one saturating red-light flash (peak at $650 \mathrm{~nm}$ ) with $3.000 \mu \mathrm{mol}$ photons $\mathrm{m}^{-2} \mathrm{~s}^{-1}$ and measured during the first second of illumination (10 $\mu$ s to $1 \mathrm{~s})$. The OJIP fluorescence transients are based on the polyphasic fast fluorescence rise from the lowest intensity $F_{O}$ (minimum fluorescence) to the highest intensity $\mathrm{F}_{\mathrm{M}}$ (maximum fluorescence) (STRASSER; TSIMILLI-MICHAEL 2001). The fluorescence intensities determined at 50, 100 and 300 $\mu \mathrm{s}\left(\mathrm{F}_{50 \mu \mathrm{s}}, \mathrm{F}_{100 \mu \mathrm{s}}\right.$ and $\mathrm{F}_{300 \mu \mathrm{s}}$, respectively), 2 and $30 \mathrm{~ms}\left(\mathrm{~F}_{2 \mathrm{~ms}}\right.$ - $\mathrm{F}_{\mathrm{J}}$ and $\mathrm{F}_{30 \mathrm{~ms}}-\mathrm{F}_{\mathrm{I}}$ ) and at FM (maximum fluorescence) were analyzed using the JIP test parameters. Strasser, TsimilliMichael e Srivastava (2004) and Tsimilli-Michael and Strasser (2008) provide an analysis of Chl fluorescence data. The intensity measured at $50 \mu$ s was the initial fluorescence $\left(\mathrm{F}_{0}\right)$. The plotted fluorescence values were the average of eight measurements of each treatment.

For determination of SDM and RDM, the plants were conditioned in a forced air circulation oven at $50 \pm 5$ ${ }^{\circ} \mathrm{C}$ until reaching a constant mass and then weighed in an analytical balance. The evaluation of NPK in soybean leaves was carried out using the plant material after drying the leaves, according to the method proposed by Tedesco et al. (1995).

Data were submitted to analysis of variance ( $\mathrm{p} \leq$ 0.05 ); and when significant, means were compared by the Tukey test at $5 \%$ probability.

\section{Results and discussion}

For soybean cv. BMX RR Potência, both in the clay and sandy soil experiments, there was no interaction between the factors soil compaction and the dose of the 
diclosulam or the isolated effect of these for the variables plant height, SDM and NPK content (Data not shown).

In previous experiments, it was observed that the preemergence diclosulam applied in clay and medium soils is safe for Monsoy M 6410 IPRO soybean, Nidera NS 6906 IPRO and Nidera NS 7000 IPRO soybean cultivars (GAZOLA et al., 2016). However, some studies have shown that pre-emergence diclosulam affected the early development of V-MAX RR soybean (NK-7059), with reduced plant growth and phytotoxicity symptoms, without reflecting on grain yield (OSIPE et al., 2014). Although the herbicide diclosulam is selective for soybean cultivars (RODRIGUES; ALMEIDA, 2011), cultivars of the same species respond differently to the stress caused by herbicides, due to their genotypic differences (LIMA et al., 2011).

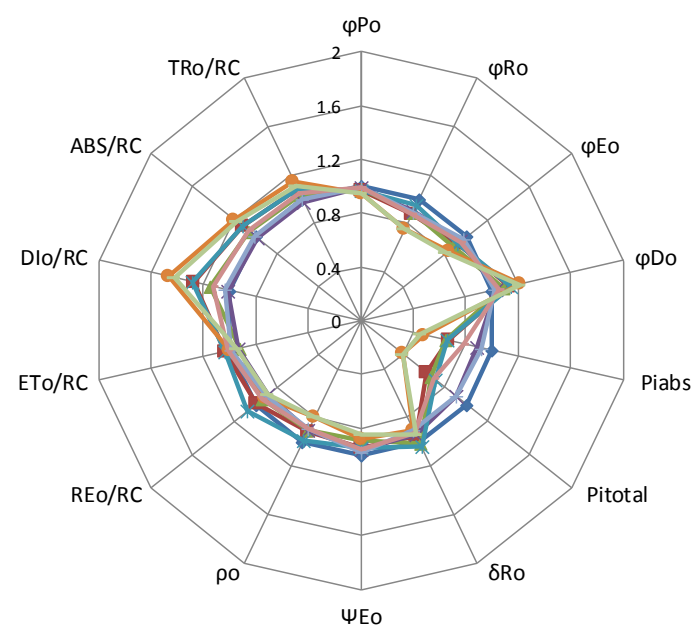

For the chlorophyll $a$ fluorescence transient variable, it was found that in the absence of compaction, independent of the soil type and the doses of the diclosulam herbicide tested, no damage was observed in the soybean compared to the control (without compaction and without herbicide). However, in the soybean plants from the clay soil when subjected to a $10 \%$ compaction in all doses of herbicide tested, as well as in the treatment without application associated with $20 \%$ compaction, a $40 \%$ reduction in photosynthetic performance parameters was observed $\left(\mathrm{PI}_{\mathrm{TOTAL}} \mathrm{e} \mathrm{PI}_{\mathrm{ABS}}\right)$, in addition to an increase of approximately $20 \%$ in the loss of energy in the form of heat $\left(\mathrm{DI}_{0} / \mathrm{RC}\right)$. When applied $20 \%$ compaction, associated with the doses of 25.2 and $50.4 \mathrm{~g}$ a.i. $\mathrm{ha}^{-1}$, a $50 \%$ reduction in $\mathrm{PI}_{\mathrm{ABS}}$ and a $40 \%$ increase in $\mathrm{DI}_{0} / \mathrm{RC}$ were observed (Figure 1A).

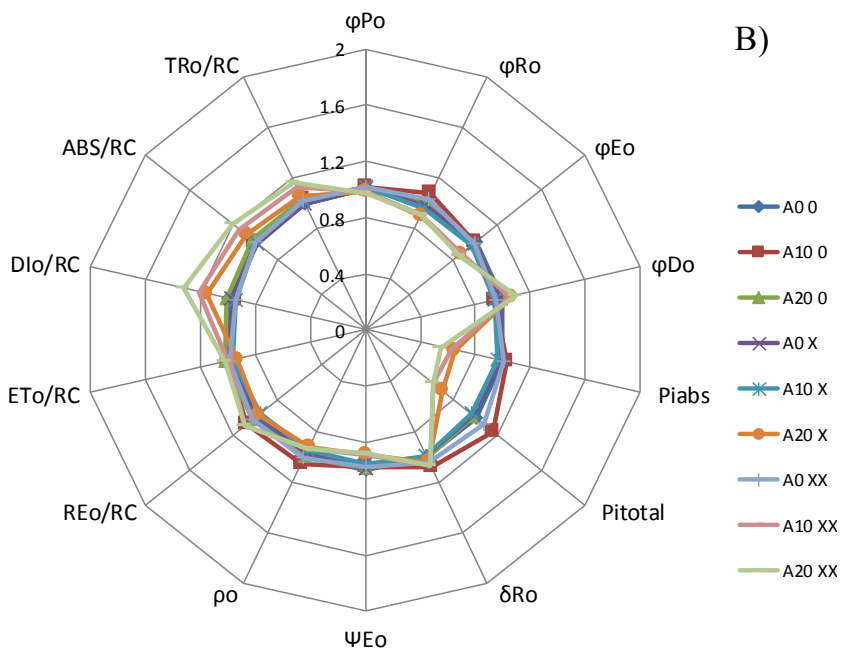

Figure 1. Chlorophyll $a$ fluorescence parameters obtained by the JIP test of cv. BMX Potência RR cultivated in clay (A) and sandy soil (B) with application of the diclosulam, at 90 days after germination (DAG), expressed in relation to control values (transformed value to 1). LEGEND: G (clay soil) and A (sandy soil): 0,10 and 20 (respectively without compaction, 10 and $20 \%$ compaction) and $0, \mathrm{X}$ and XX (respectively without herbicide, 25.2 and $50.4 \mathrm{~g}$ ai ha ${ }^{-1}$ ).

In sandy soil, plants subjected to $10 \%$ compaction at a dose of $50.4 \mathrm{~g}$ a.i. $\mathrm{ha}^{-1}$, as well as those subjected to $20 \%$ compaction associated with the 25.2 and $50.4 \mathrm{~g}^{\text {a.i. }} \mathrm{ha}^{-1}$ doses of the diclosulam herbicide showed a reduction $\left(\mathrm{PI}_{\mathrm{TOTAL}} \mathrm{e} \mathrm{PI}_{\mathrm{ABS}}\right.$ ) in comparison to the control (without compaction and without herbicide) (Figure 1B).

Soil compaction, regardless of texture, may favor the ready availability of the herbicide in the soil solution, and thus the plants are exposed to larger amounts of the herbicide, causing intoxication in the soybean plants. This is because the metabolism mechanism of plants is overloaded, since the process of selectivity of the crop to the herbicides of the sulfonanilides group is due to the metabolic detoxification as a function of the hydroxylation (oxidation reaction), followed by the conjugation of glucose (HODGES; DE BOER; AVALOS, 1990). However, this stress was not enough to decrease the accumulation of biomass and plant height, suggesting that the herbicide diclosulam caused reversible damage to the photosynthetic apparatus; as observed in pineapple plants, the herbicide amicarbazone caused reduce in the photosynthetic pigment content without interfering in height and biomass accumulation (CATUNDA et al., 2005).

Regarding the potential carryover of the diclosulam in corn successively to soybean, there was no interaction in both soils used nor an isolated effect of the factors tested for SDM, RDM and RL. However, for the clay soil, an isolated effect of the compaction factor was observed for the plant height (Figure 2). There was a reduction of corn plants height of approximately $11 \%$ when submitted to the level of compaction of 10 and $20 \%$ (Figure 2) when compared to the treatment without compaction. Reduction in plant height was also observed in corn plants sown 90 days after application of the herbicides imazaquin, diclosulam and imazethapyr, with a reduction of $5.2 ; 5.7$ and $3.9 \%$, respectively (DAN et al., 2012). This reduction may be related to the difficulty of developing corn roots due to soil compaction. 
SOUZA, A. S et al.

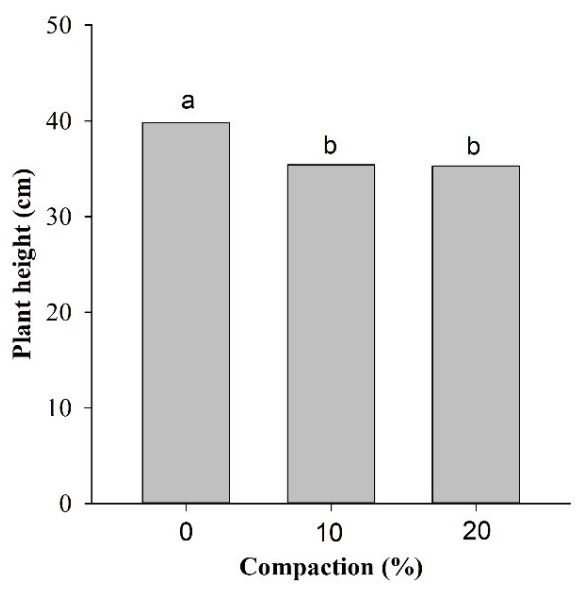

Figure 2. Plant height of corn plants at 45 days after germination (DAG), under soil compaction of 0,10 and $20 \%$, cultivated in clay soil 90 days after diclosulam application. Means followed by the same letter do not differ from each other by the Tukey test at $5 \%$ probability. Coefficient of variation $=16.7 \%$.

For chlorophyll $a$ fluorescence analyzes, corn plants in clayey soil, in all evaluations, showed no difference in photosynthesis parameters between the treatments evaluated

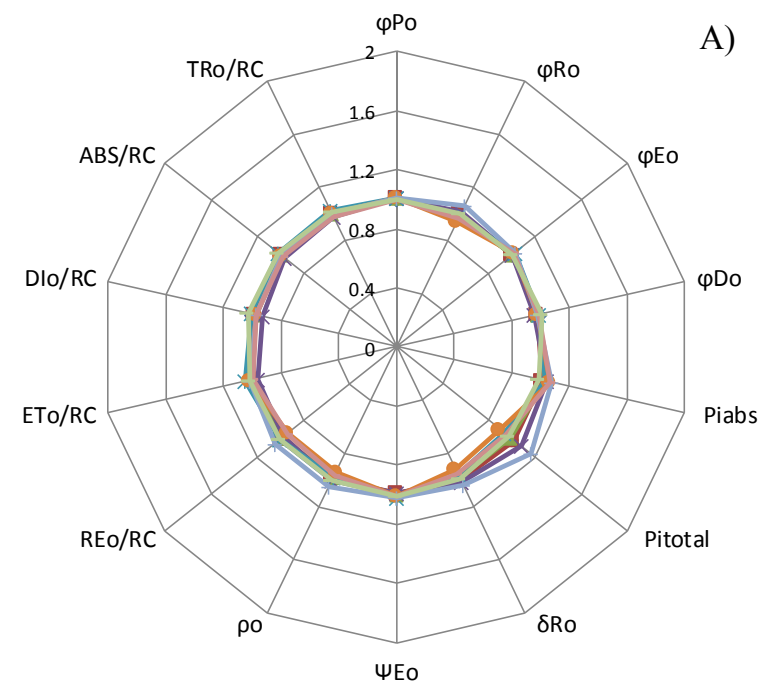

(herbicide doses and compaction levels), when compared to the control. (Figure 3).

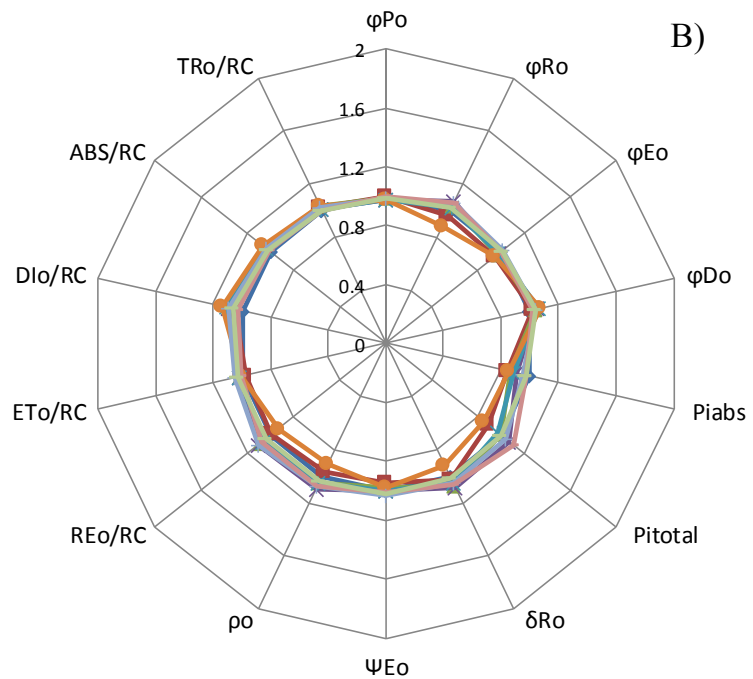

C)
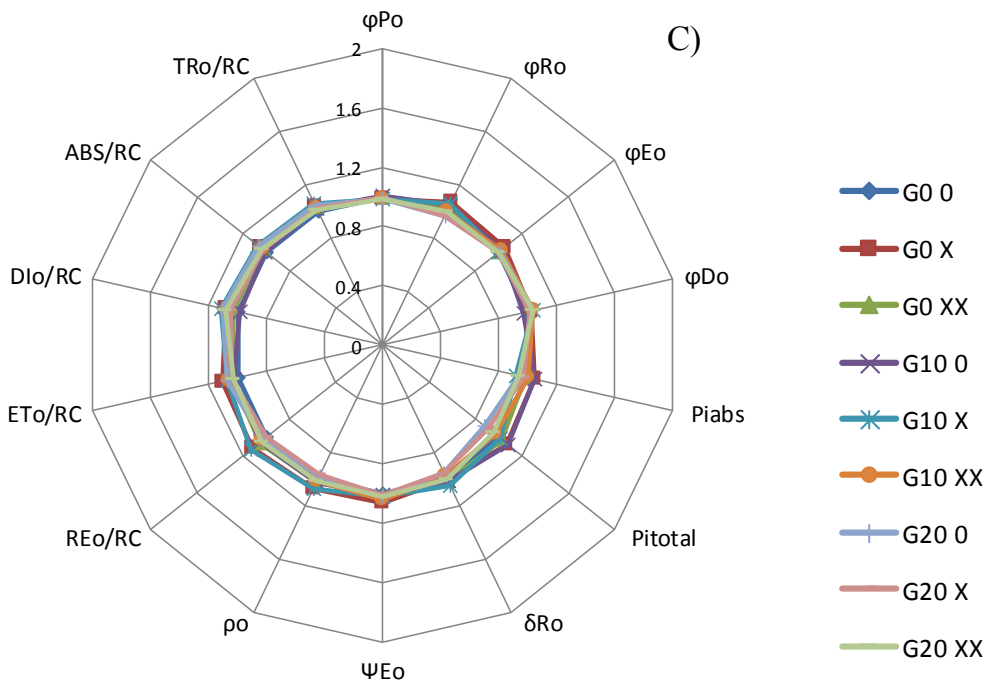

Figure 3. Chlorophyll $a$ fluorescence transient parameters obtained by the JIP test of corn plants at 15 (A), 30 (B) e 45 (C) days after germination (DAG) cultivated in clay soil with application of the diclosulam expressed in relation to control values (transformed value to 1). LEGEND: G (clay soil): 0,10 and 20 (respectively without compaction, 10 and 20\% compaction) and 0 , X and XX (respectively without herbicide, 25.2 and $50.4 \mathrm{~g}$ ia ha $^{-1}$ ). 
SOUZA, A. S et al.

In the sandy soil, at $15 \mathrm{DAG}$, for all the evaluated treatments, increase between 10 and $30 \%$ of the parameters related to the photosynthetic performance $\left(\mathrm{PI}_{\mathrm{TOTAL}}\right.$ e $\left.\mathrm{PI}_{\mathrm{ABS}}\right)$ was verified, in comparison to the control, which demonstrates greater metabolic activity without damaging the plants (Figure 4A). At 30 and $45 \mathrm{DAG}$, no difference

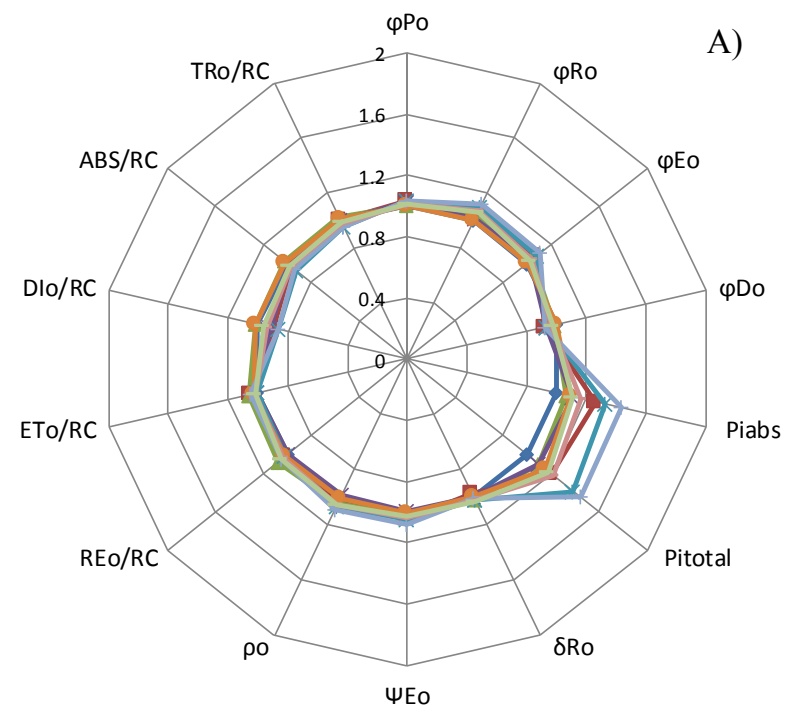

was observed for the photosynthesis parameters between the plants submitted to the treatments when compared to the control, which demonstrates the normal metabolic activity of these plants in all evaluated treatments (Figures 4B and $4 \mathrm{C})$.

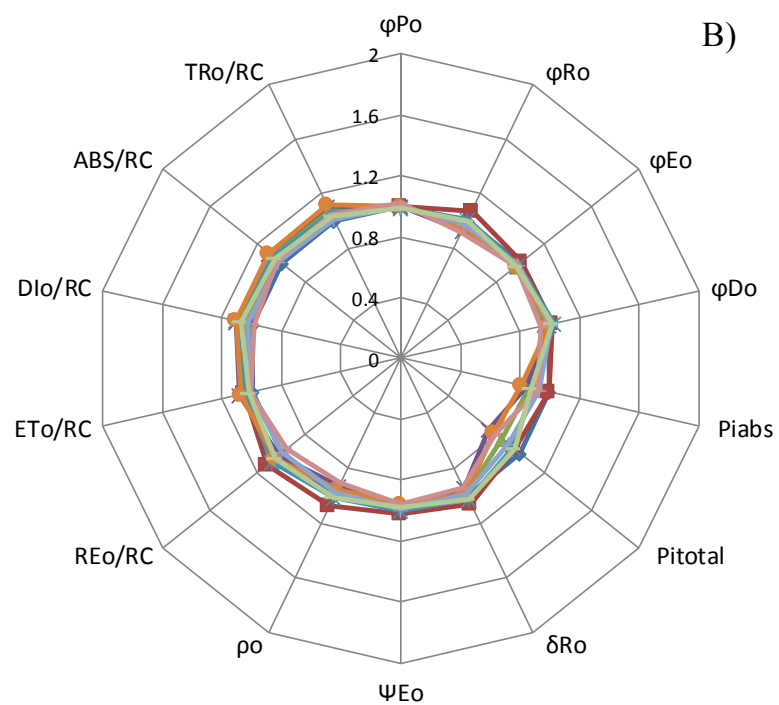

C)
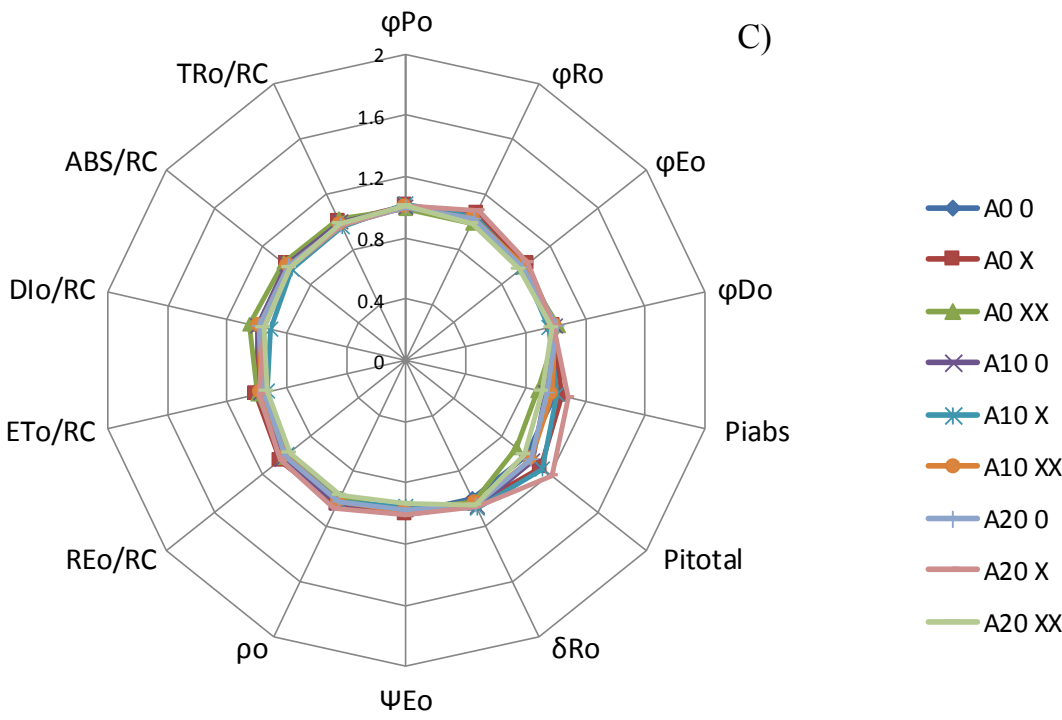

Figure 4. Chlorophyll $a$ fluorescence parameters obtained by the JIP test of corn plants at 15 (A), 30 (B) e 45 (C) days after germination (DAG) cultivated in sandy soil with application of the diclosulam expressed in relation to control values (transformed value to 1). LEGEND: A (sandy soil): 0,10 and 20 (respectively without compaction, 10 and 20\% compaction) and 0 , X and XX (respectively without herbicide, 25.2 and $50.4 \mathrm{~g}_{\text {ia ha }}{ }^{-1}$ ).

No significant damage was observed in the growth parameters in the corn crop sown 90 days after the application of diclosulam in the pre-emergence of soybeans. The data corroborate with other authors, where it was observed that the herbicide diclosulam reduces the corn yield in succession to soybean, if these are sown up to 30 days after its application of the herbicide (ARTUZI; CONTIERO, 2006). Other authors point out that residual activity of the herbicides flumioxazin, imazaquin and diclosulam was not enough to reduce the yield of pearl millet cultivated in succession to soybean (DAN et al.,
2011).

In addition to the effect of carryover on the corn crop, the residual herbicidal effect diclosulam was tested in the soil through bioassay using cucumber as bioindicator plant, and by the quantification of the herbicide in the soil. For the cucumber plants in both soils tested there was no interaction between the factors for any of the analyzed variables. In the clay soil experiment, an isolated compaction effect was observed for the RL and RDM variables, while in the sandy soil compaction effect was observed for the SDM, RL and RDM variables. There was 
SOUZA, A. S et al.

no herbicide dose effect for any of the variables analyzed.

When the clay soil was evaluated, no difference was observed in root dry mass (Table 2), in uncompacted soils and with $10 \%$ of compaction. However, when applying $20 \%$ of compaction at 25.2 and $50.4 \mathrm{~g}$ a.i. $\mathrm{ha}^{-1}$, there was a reduction in the RDM of the bioindicator plants compared to the control without herbicide application, and the reduction was observed at $50 \%$ (Table 2). Cucumber plants prove to be good bioindicators for different pre-emergent herbicides, including metribuzin. In a study with metribuzin herbicide and using cucumber as a bioindicator, the authors verified that there was plant phytotoxicity when cultivated in soil with residual herbicide regardless of the characteristics of the soil tested (SILVA JUNIOR; QUEIROZ; MARTINS, 2015).

Table 2. Plant height, dry shoot mass and dry mass of the roots of cucumber plants (bioindicator specie) at 45 days after germination (DAG) in clay soils cultivated 90 days after the application of diclosulam.

\begin{tabular}{|c|c|c|c|c|c|c|c|c|c|}
\hline $\begin{array}{c}\text { Dose } \\
\left(\mathrm{g} \mathrm{ai} \mathrm{ha}^{-1}\right)\end{array}$ & \multicolumn{3}{|c|}{ Plant height (cm) } & \multicolumn{3}{|c|}{ Shoot dry mass (g) } & \multicolumn{3}{|c|}{ Root dry mass (g) } \\
\hline \multicolumn{10}{|c|}{ Compaction (\%) } \\
\hline & 0 & 10 & 20 & 0 & 10 & 20 & 0 & 10 & 20 \\
\hline $\mathbf{0}$ & $9.5^{\mathrm{ns}}$ & $9.4^{\mathrm{ns}}$ & $10.1^{\mathrm{ns}}$ & $0.16^{\mathrm{ns}}$ & $0.15^{\mathrm{ns}}$ & $0.20^{\mathrm{ns}}$ & $0.04^{\mathrm{ns}}$ & $0.063^{\text {ns }}$ & $0.07 \mathrm{a}$ \\
\hline 25.2 & 8.6 & 9.2 & 9.1 & 0.17 & 0.17 & 0.16 & 0.04 & 0.045 & $0.03 \mathrm{~b}$ \\
\hline 50.4 & 8.6 & 7.6 & 8.6 & 0.15 & 0.14 & 0.16 & 0.05 & 0.043 & $0.03 \mathrm{~b}$ \\
\hline CV (\%) & & 23.7 & & & 23.3 & & & 48.4 & \\
\hline
\end{tabular}

Means followed by the same letter in the column do not differ from each other by the Tukey test at $5 \%$ probability. ns $=$ not significant.

The root length was influenced by the level of soil compaction and a reduction in root length was observed with increasing compaction (Figure 5). In soil with 20\% compaction, there was a $28 \%$ reduction in the length of roots of the bioindicator plant compared to the treatment without compaction, evidencing that the soil density influences the growth and development of the plant (Figure 5).

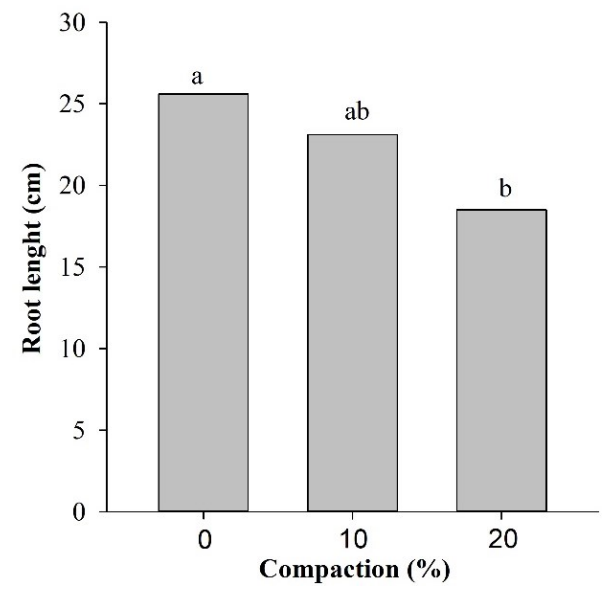

Figure 5. Root length of cucumber plants (bioindicator species) at 45 days after germination (DAG), grown in clay soil 90 days after the application of diclosulam herbicide. Means followed by the same letter do not differ from each other by the Tukey test at $5 \%$ probability. Coefficient of variation $=37.2 \%$.

In sandy soil, no statistical significance was observed for plant height for both factors, compaction and herbicide dose (Table 3). For the variable shoot dry mass (Table 3), difference was observed only in soil with $20 \%$ compaction, with a reduction of 30 and $50 \%$ of root dry $n$ the presence of 25.2 and $50.4 \mathrm{~g}$ a.i. $\mathrm{ha}^{-1}$ of diclosulam, respectively. 
Table 3. Plant height $(\mathrm{PH})$ and shoot dry mass (SDM) of cucumber plants (bioindicator specie) at 45 days after germination (DAG), grown in sandy soil, 90 days after the application of diclosulam.

\begin{tabular}{lcccccc}
\hline \multicolumn{3}{c}{ PHose $\left(\mathrm{g} \mathrm{ai} \mathrm{ha}^{-\mathbf{1}}\right)$} & \multicolumn{3}{c}{ Compaction (\%) } & \multicolumn{3}{c}{ SDM (g) } \\
\hline & 0 & 10 & 20 & 0 & 10 & 20 \\
$\mathbf{0}$ & $16.0^{\mathrm{ns}}$ & $16.4^{\mathrm{ns}}$ & $16.4^{\mathrm{ns}}$ & $0.39^{\mathrm{ns}}$ & $0.47^{\mathrm{ns}}$ & $0.55 \mathrm{a}$ \\
$\mathbf{2 5 . 2}$ & 16.0 & 15.5 & 15.3 & 0.38 & 0.41 & $0.38 \mathrm{~b}$ \\
$\mathbf{5 0 . 4}$ & 14.9 & 14.0 & 14.6 & 0.46 & 0.35 & $0.28 \mathrm{~b}$ \\
\hline CV (\%) & \multicolumn{3}{c}{19.4} \\
\hline
\end{tabular}

Means followed by the same letter in the column do not differ from each other by the Tukey test at $5 \%$ probability. ns $=$ not significant.

For the root length, approximately $30 \%$ reduction was observed for the two compaction levels evaluated in the test (Figure 6). The root dry mass decreased 28 and $62 \%$, when compared to uncompacted, for compaction levels of 10 and $20 \%$, respectively, regardless of the presence or absence of herbicide (Figure 6). Similar results were observed, where the increase of soil density affected the biometric variables of soybean cultivation more strongly than the presence of the herbicide sulfentrazone (ZOBIOLE et al., 2007).

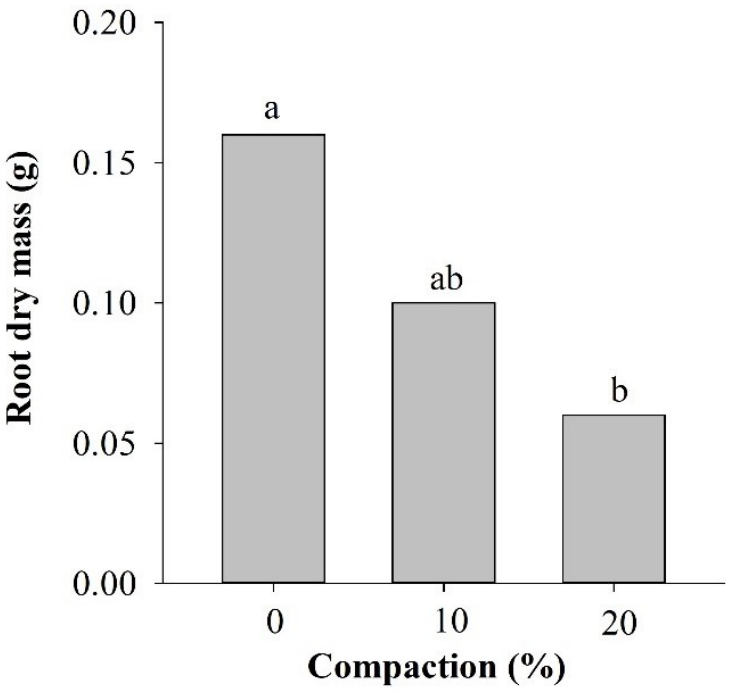

Figure 6. Root length (left) and root dry mass (right) of cucumber plants (bioindicator specie) at 45 days after germination (DAG), grown in sandy soil, 90 days after application of the herbicide diclosulam. Means followed by the same letter do not differ from each other by the Tukey test at $5 \%$ probability. Coefficient of variation $=32.6 \%(\mathrm{RL})$ and $37.2 \%(\mathrm{SDM})$.

In the direct quantification of the herbicide residue in the soil, in all the analyzed samples, the presence of the herbicide by the MS/Modified QuEChERS Method and analyzed by LC-MS. Diclosulam was not detected at the detection limit (LOD) of $0.0025 \mathrm{mg} \mathrm{kg}^{-1}$ and quantification limited (LOQ) of $0.0083 \mathrm{mg} \mathrm{kg}^{-1}$. The absence of residue by the chromatographic method does not ensure that there is no herbicide in the soil. In this case, the limit of detection and quantification may have been greater than the amount of herbicide in the sample.

As previously seen, the results of the bioassay show a reduction in shoot dry mass when applied $50.4 \mathrm{~g}^{\text {ai }} \mathrm{ha}^{-1}$ and $20 \%$ soil compaction. Results such as this demonstrate the importance of using bioindicators of residues, since in some cases they may be more sensitive than the chemical methods applied.

\section{Conclusions}

In soybean plants cultivated in clay soils, compaction caused damage to photosynthesis of the plants, regardless of the presence or absence of the herbicide diclosulam, which was aggravated by the increase in compaction, but did not reflect the biometric variables evaluated. In soybean cultivated on sandy soils, the application of the diclosulam herbicide does not cause damage to the crop in soils with no compaction.

The diclosulam herbicide, regardless of the compaction levels, did not cause damage to the corn crop in succession to soybean (90 days after application of the herbicide) up to the dose of $50.4 \mathrm{~g}_{\text {ai }} \mathrm{ha}^{-1}$. In clay soils, the presence of soil compaction interferes with the development of crop plants, independently of the presence or absence of the herbicide in the soil. 
By the quantification method, no residue of the diclosulam herbicide was detected in the two evaluated soils at 94 days after application. By the bioassay method it was observed that the presence of high compaction affects the development of the plants, which could result in the herbicide residue in the soil, but without this cause damage to the corn sown in succession to soybean.

\section{Acknowledgement}

To Fundação Carlos Chagas Filho de Amparo à Pesquisa do Estado do Rio de Janeiro (FAPERJ) and the Coordenação de Aperfeiçoamento de Pessoal de Nível Superior (CAPES), for scholarships and financial assistance.

\section{References}

Artuzi, J. P.; Contiero, R. L. Herbicidas aplicados na soja e produtividade do milho em sucessão. Pesquisa Agropecuaria Brasileira, v. 41, n. 7, p. 1119-1123, 2006.

Blanco, H. G. Destino, comportamento e resíduos dos herbicidas no solo. O Biológico, v. 45, n. 11, p. 225-248, 1979.

Catunda, M. G.; Freitas, S. P.; Oliveira, J. G.; Silva, C. M. M. Efeitos de herbicidas na atividade fotossintética e no crescimento de abacaxi (Ananas comossus). Planta daninha, v. 23, n. 1, p. 115-121, 2005.

Chen, G. R. R.; Weil, R.; Hill, L. Effects of compaction and cover crops on soil least limiting water range and air permeability. Soil and Tillage Research, v. 136, p. 61-69, 2014.

Dan, H. A.; Dan, L. G. M.; Barroso, A. L. L.; Neto, A. M. O.; Guerra, N. Resíduos de herbicidas utilizados na cultura da soja sobre o milho cultivado em sucessão. Revista Caatinga, v. 25, n. 1, p. 86-91, 2012.

Dan, H. A.; Dan, L. G. M.; Barroso, A. L. L.; Procópio, S. O.; Oliveira JR.; R. S. Assis; R. L. Silva, A. G. Feldkircher, $\mathrm{C}$; Atividade residual de herbicidas pré-emergentes aplicados na cultura da soja sobre o milheto cultivado em sucessão. Planta Daninha, v. 29, n. 2, p. 437-445,

Ferri, M. V. W.; Vidal, R. A.; Merotto Junior, A.; Fleck, N. G. Atividade dos herbicidas flumetsulam e trifluralim em diferentes valores de $\mathrm{pH}$ e densidade do solo. Ciência Rural, v. 30, n. 1, p. 11-15, 2000.

Gazola, T.; Dias, M.; Belapart, D.; Castro, E.; Bianchi, L. Efeitos do diclosulam na soja cultivada em solos de diferentes classes texturais. Revista Brasileira de Herbicidas, v. 15, n. 4, 353-361, 2016.

Guerra, N.; Oliveira Júnior, R. S.; Constantin, J.; Oliveira
Neto, A. M. Seleção de espécies bioindicadoras para os herbicidas trifloxysulfuron-sodium e pyrithiobac-sodium. Revista Brasileira de Herbicidas, v. 10, n. 1, p. 37-48, 2011.

Hodges, C. C.; De Boer, G. J.; Avalos, J. Uptake and metabolism as mechanism of selective herbicide activity of the 1, 2, 4 - Triazolo [ 1, 5 - $\alpha$ ] pyrimidines. Pesticide Science, v. 29, n. 3, p. 365-378, 1990.

Lima, R. A. F.; Dittrich, V. A. O.; Souza, V. C.; Salino, A.; Breier, T.B.; Aguiar, O. T. Flora vascular do Parque Estadual Carlos Botelho. Biota Neotropica, v. 11, n. 4, p. 173-214, 2011.

Melo, C.; Dias, R.; Mendes, K.; Assis, A.; Reis, M. Carryover de herbicidas em sistemas cultivados com olerícolas. Revista Brasileira de Herbicidas, v.15, n.1, p. 67-78, 2016.

Müller, M. M. L.; Ceccon, G.; Rosolem, C. A. Influência da compactação do solo em subsuperfície sobre o crescimento aéreo e radicular de plantas de adubação verde de inverno. Revista Brasileira de Ciência do Solo, v. 25, n. 1, p. 531538, 2011.

Rodrigues, B. N.; Almeida, F. S. Guia de herbicidas. 6. ed. Londrina: Grafmarke, 2011. 697 p.

Secco, D.; Reinert, D. J.; Reichert, J. M.; Silva, V. R. Atributos físicos e rendimento de grãos de trigo, soja e milho em dois Latossolos compactados e escarificados. Ciência Rural, v. 39, n. 1, p. 58-64, 2009.

Senseman, S. A. (Ed.). Herbicide handbook. 9 ed. Lawrence: Weed Science Society of America, 2007. 458 p.

Silva Junior, A. C.; Queiroz, J. R. G.; Martins, D. Quantidade de chuva e lixiviação do herbicida metribuzim através de bioindicador. Revista Brasileira de Engenharia Agrícola e Ambiental, v. 19, n. 6, p. 592-597, 2015.

Soracco, C. G., Lozano, L. A., Villarreal, R., Palancar, T. C., Collazo, D. J., Sarli, G. O., Filgueira, R. R. Effects of compaction due to machinery traffic on soil pore configuration. Revista Brasileira de Ciência do Solo, v. 39, n. 2, p. 408-415, 2015.

Strasser, R. J.; Stirbet, A. D. Estimation of the energetic connectivity of PS II centers in plants using the fluorescence rise $\mathrm{O}-\mathrm{J}-\mathrm{I}-\mathrm{P}$; fitting of experimental data to three different PS II models, Mathematics and Computers in Simulation, v. 56, n. 4-5, p. 451-462, 2001.

Strasser, R. J.; Tsimilli-Michael, M., Srivastava, A. Analysis of the chlorophyll fluorescence transient, In: G.C. Papageorgiou, Govindjee (Eds.), Chlorophyll Fluorescence: A Signature of Photosynthesis, Advances in Photosynthesis and Respiration, Springer, Dordrecht: The Netherlands, v. 19, 2004. p. 321-362. 
Tedesco, M. J.; Gianello, C.; Bissani, C. A.; Bohnen, H.; Volkweiss, S. J. Análise de solo, plantas e outros materiais. 2. ed. Porto Alegre: Universidade Federal do Rio Grande do Sul, Departamento de Solos, 1995. 118 p.

Tsimilli-Michael, M.; Strasser, R. J. In vivo assessment of plants' vitality: applications in detecting and evaluating the impact of my corrhization on hostplants, in: A. Varma. (Ed.). Mycorrhiza: State of the Art, Genetics and Molecular Biology, Eco-Function, Biotechnology, EcoPhysiology, Structure and Systematics, 3rd ed., Springer, Dordrecht: The Netherlands, 2008. p. 679-703.

Zobiole, L. H. S.; Oliveira JR, R. S.; Tormena, C. A.; Constantin, J.; Cavalieri, S. D.; Alonso, D. G.; Brighenti, A. M.; Castro, C. Effect of Soil Compaction and Sulfentrazone on Soybean under Two Soil Moisture Conditions. Planta Daninha, v. 25, n. 3, p. 537-545, 2007. 